\title{
The Holy Spirit and Other Spirits in Asia: \\ Discernment of Spirits in Non-Christian Religions 98
}

Cheong Weng Kit

\section{A. Introduction}

Malaysia is an ethnically diverse and religiously pluralistic nation. Within its population Christians number $9.2 \%$ while the remainder is comprised of Muslims (61.3\%), Buddhists (19.8\%), Hindus (6.3\%), and other religions (3.4\%) such as Confucianism, Taoism, folk/traditional/animistic religions, and others (Department of Statistics Malaysia, 2010). It is thus not surprising that any non-Christian to Christian encounter should implicate followers of Jesus, who are trying to understand whether non-Christians may be following the right path towards truth and also whether the spirits they worship are in any biblical sense the Spirit of truth of which Jesus speaks (Jn. $14: 17 ; 15: 26 ; 16: 13$ ) or that of another spirit. If interreligious relationships can be understood in this context, then the task of discerning the spirits, whether it is the Holy Spirit or "other" spirits at work, is of great importance.

Biblically, all Christians are called to discern the spirits (1 Jn. 4:1-3) of those at work in this world as well as the truth or error that may be perpetuated behind these spirits. In Mt. 24:24 (NRSV) Jesus warns his followers that "false messiahs and false prophets will appear and produce great signs and omens to lead astray, if possible, even the elect." If Jesus' warning is an important note for Christians to heed, the question that should be asked is how then should Christians engage with supernatural forces or spirit entities that may exist among people of other religions outside of Christianity? What should we do when we encounter people who state that

\footnotetext{
98 Reprinted with permission from "Contextual reflections from Asia (A special publication from the faculty and friends of Sabah Theological Seminary in honour of its 25th anniversary). ” eds., Cheong Weng Kit et al., 226-255. Kota Kinabalu: Sabah Theological Seminary. 2013
} 
they "hear voices" telling them that "all is well" if they follow these spirits, but such paths are outside biblical understanding (Eadie 1992)? How can we tell if a person is merely psychotic or actually demonized (Moore 1977)? And what about non-Christians who share about dreams telling them follow Jesus (Musk 1988)?

I submit that in Asia such questions are contextually and theologically important, socially and religiously relevant, and pastorally urgent. This is so because Asians, and Malaysians in particular, live most of their everyday lives hearing such stories from friends or relatives, experiencing personal encounters with the spirit world (whether ghosts, evil spirits or other beings), or following religious beliefs that reinforce the notion of an enchanted/spiritfilled existence. Almost everywhere, the presence of spirits being real and constant, whether they are perceived or experienced, is a reality one must deal with at some time or another when doing ministry in Asia.

Even so, few writings from western Christians have engaged with this reality. Instead, most materials on interreligious relationships deal with dialogue, service, friendship, or other areas, but hardly on how one might relate to the spirits that exist in other religions. The spirit world with its evil spirits, it seems, hardly exists or is considered unimportant for discussion. For any serious work of Asian contextual theology to occur, this consideration cannot be ignored.

Where they are present, such writings are mostly popular and academic evangelical Christian works. They usually posit a dichotomy of good/evil or Holy Spirit/evil spirits when discussing the discernment of spirits (Dickason 1987; Hanegraff 1993; Hillstrom 1995; McBain 1992). This article asks whether this manner of understanding and discerning the spirits is overly simplistic. In addition, it will briefly survey and critique the practice of spirit discernment historically in the church as well as the psychological, anthropological, and biblical aspects. In particular, Amos Yong, a Malaysianborn theologian that now resides in America, and his theology of discernment of spirits will be examined. In the final section a proposed 
hermeneutic of spirit discernment will be constructed by utilizing the strengths of Christian reflections across the disciplines, traditions and history as well. Its overall objective is to equip the church, its ministers, missionaries, and workers to discern spirit entities so that they may lead others to Christ, cooperate with the movements of God's Spirit in other religions, stand in opposition to evil spirits, and train the Christian heart and mind to become more spiritually sensitized to the phenomenon of the spirits at work in this world.

\section{B. The discernment of spirit in anthropology and psychology}

The warrant for discerning the spirits is found in 1 Cor. 12:10; 2 Cor. 11:4; 1 Thess. 5:19-22; 2 Thess. 2:2 and 1 Jn. 4:1, 3, 6 (Kim 2007:23 citing Dunn). Identifying and discriminating them is also an ideological act, a social interpretation, and an epistemological statement that defines good and evil, and also includes the boundaries between them (Caciola 2003:1). It is an interpretation because local understandings of the spirit world and their selfinterest as exigencies of power among the observers come into play (ibid., 125).

A proper understanding of the religious experience, i.e., the epistemology of experience, is also important; otherwise, one may reduce talk about the "spirit" as a euphemism (e.g., an angry person is said to have an "angry spirit") (Wiebe 2004:23, 28-29). The character of such supernatural forces naturally predisposes a discussion concerning the identity of such spiritual forces, i.e. demons, angels, Holy Spirit, or otherwise. On this subject there is a wide debate concerning the ontology, identity, and warfare aspects of these forces (e.g., Hiebert 1994:203-215; McConnell 1997; Wink 1986; 1992). I am not interested in identifying, mapping, or warfare involving the spirit world but merely to develop a methodology of discernment. Such a venture may risk an over concern or preoccupation in a world populated by entities to the detriment of other more important missiological or pastoral concerns. Nonetheless, I make this attempt because of an observed limited 
Christian attention in this area as well as the obvious biblical call and warrant for it.

Anthropologically, spirit discernment involves the communication with or divination of spirits (Lehmann and Myers 1997; Wilson 2000:375).99

Discernment and descriptions of people in out-of-body experiences (OBE) being led by spirit guides are also found in psychological and New Age literature. There, we see experimentations with alternate states of human consciousness (ASC) and experiences involving the human spirit and its life after death experiences or interests in spirit guides (Eadie 1992; Hillstrom 1995:30, 84, 96; Rago 1983:88-106). Examining these experiences reveals some common features (Hillstrom 1995:211-215):

1. They appear to convey a spiritual message.

2. All the experiences seem very real.

3. The experiences are timely.

4. Many are associated with ASC.

5. Apparent spirit contacts that convey similar messages are involved.

6. These apparent spirit contacts are followed by "paranormal aftereffects".

Such ASC experiences opened people to receive spirit guides that were accessible through drugs, trances, deep meditation, and sleep (Hillstrom 1995:38). These occurrences are also common in Asian religions, particularly in animism. Hillstrom comments that

True separations of body and spirit that are deliberately induced and have nothing to do with death simply do not fit with scriptural teachings. According to the Bible, the separation of body and spirit is synonymous with death (for instance, see $1 \mathrm{Kg}$. 17:20-22; Eccl. 12:7; Mt 10:28; Luke. 8:53-55) and death is not a trivial event. It was ordained by God as a punishment for sin (Gen. 3:17-19; Rom. 5:12;

99 Divination involves the "discovery by supernatural means of hidden knowledge, including knowledge of the future" (Wilson 2000: 375). 
6:23), it occurs only once (except by divine intervention; Heb 9:27), and its timing is evidently controlled by God, not by our own choice. (Hillstrom 1995: 86)

Where some experiences are truly aberrant, one has to decide whether they are demonic possession or rather human/personal obsession such as hysteria, delusional insanity, or a secondary personality (Moore 1977:94-96). Other ASC occurrences such as dream sleep or trances, near-death experiences (NDE), channeling, and extra-sensory perception (ESP) may be areas where the supernatural intersects with the psychological (Hillstrom 1995:90-91, 178-183; Moore 1977:98). Concerning channeling or the use of mediums, Christians are not to contact them (Lev. 19:31; Deut. 18:9-12; 1 Sam. 28:7-19) lest they become conduits of malevolent spirits (Deut. 32:1517). In New Age and nature religions, the implications are that when people are opened to ASC and similar types of experiences, they are then exposed to the unknown and also great personal harm by evil entities. Even if such experiences seem to be uplifting to the person, discerning the content of these experiences is important; for there are also negative NDEs that include troubling or hellish visions (ibid., 92).

Psychologically, the human spirit and mind also has as much a role in any expression of spiritual phenomena apart from supernatural causes; in fact, it may explain many of the above experiences. While modernity dismisses malevolent spiritual influences as a cause of bodily ills, in ancient times it was not so (Wiebe 2004:26).100 To be sure, Christians cannot conclude all bodily ills are caused by physical sources (Hillstrom 1995:219).

If demonic influences affect humans, according to Paul Tillich (1963:114), demonic possession "destroys the rational structure of the mind when particular forces in the personality are elevated, claim superiority over others and thereby split the consciousness". He also (1963:114) notes that in of the Lord, God could inflict bodily harm to them as well (Acts 10:8-11). 
a demon-possessed state, the mind is not really "beside itself"; rather it is in the power of elements which aspire to control the whole mind and which grasp the center of the rational self to destroy it. It is "a psychological disorder in which people exhibit behaviors that suggest that their personalities have been segmented" (Wiebe 2004:9). In this area multiple personality disorder or dissociative identity disorder (DID) is of interest. Theologians however admit difficulty distinguishing between demonic influence related to mental illness and ecstatic experiences (Guillet 1970:37). For Yong (2000:238), "phenomenologically, violent or uncontrolled behavior ... all have often been understood to signify at least demonic oppression if not possession [that] exhibits a loss of self-control, which is contrary to the biblical account whereby divine and human come together as counterbalanced forces." Yong (2003:130-137) attributes this factor to entities that emanate a "force field". I shall discuss this phenomenon in a later section.

Here, some distinctions must be made between the disorder and the demonic: DID is a defense mechanism that helps people cope with life's trauma, while for the demonic, some symptoms may include ASC experiences when spiritual topics are brought up; and they may experience persistent, bizarre dreams (Wiebe 2004:49). However, for those who experience divine ecstasy, the human mind goes beyond reason itself, even beyond the subject-object structure of normal thought. Here reason is neither denied nor negated, while demonic possession destroys them (ibid., 56).

We should note that Scripture never informs Christians to suspend their mind or consciousness in any engagement with the supernatural. Rather, the injunctions to prove (2 Cor. 13:5), test (1 Thess. 5:21; 1 Tim. 3:910; 1 Jn. 4:1-2), examine (1 Cor. 9:3; 11:28), discern (Rom. 12:1-2) and think (2 Tim. 4:7; Phil. 4:8) about these things testify to the absolute importance of the mind in distinguishing good or evil. Where meditation is concerned (Josh 1:8; Ps.1: 2; 119:15), Christians are to fill their mind with God, never to empty it (Foster 1988:20) as eastern religions or New Agers are 
accustomed to doing. In fact Scripture never suggests Christians should seek meditation for its own sake. Rather, it is a way to pursue God alone. Where so called Christian ASC experiences like visions or dreams may be experienced, they are not directly sought after but come unbidden (Gen. 31:11; 40:9-11; Acts 9:3-7; 18:9; 23:11; Matt. 2:12; 2 Cor. 12:1-4).

In summary, anthropology and psychology open up the possibility for Christians to understand that unusual spirit expressions may not necessarily be demonic or divine but may be caused by the human spirit. Christians thus cannot ignore this dimension but must judge such phenomenon as either divine or demonic (Moore 1977:105).

\section{The discernment of spirits in Christianity}

\section{Discernment in biblical times}

In biblical times "spiritual discernment is ... clearly related to the kingdom of God [and] is a prophetic task. Hence, the importance of the criteria of discernment in Israel" (McNamara 1979: vii). The Old Testament provides some criteria that may reveal the spirits that influence seers (Guillet 1970:21-22):

(1) A prophecy of misfortune is normally authentic; a prophecy of good fortune is authentic only when it is verified by the event (Deut. 18:2122; Jer. 28:8-9).101

(2) The true prophet, in order to uphold his words, often proposes signs that come to pass and that prove he is speaking in the God's name (1 Sam. 21:34; 10:7-8; 2 Kg. 19:29; 20:9).

101 McNamara (1979:10-13) notes that the fulfillment of prophecy as specified in Deut.18: $20-22$ is of limited utility and value only when "restricted to the time of the prophet and his contemporaries," as it ignores the principle in Jer. 18:7-10 that some prophecies are in God's mind subject to people's response with regard to their fulfillment. 
(3) An extraordinary event happening according to a prophet's word will not guarantee that he is sent by God, if his doctrine is at odds with Israel's religion. (Deut. 13:23).

(4) A prophet's behavior is as important as his doctrine (Jer. 23:14; 29:23).

(5) Moral conduct is the criterion of the prophet's intention (Jer. 23:16$17)$.

In the New Testament the supreme discerner of spirits was Jesus. When demons are confronted with Christ's reality and his followers, they speak the truth of Jesus' presence and ministry to the extent that Jesus had to silence them (Matt. 8:29; Mk. 1:23-24, 34; 3:10-12; Lk. 4:33-35). Even Paul had to exorcise a spirit that proclaimed the truth of his ministry (Acts 16:16-18). Thus while demoniacs could testify divine truths, they were rejected by Jesus and Paul (Weibe 2004:31). Sure biblical tests for discerning proclaimed truth were (1) a confession of Christ's true nature (1 Jn. 4:1) and (2) true fruit borne through a speaker's actions (Matt. 7:16).

Interestingly, the four Gospels seldom mention Jesus discerning the spirits among people (Matt. 16:17-23; Jn. 8:43-45). Rather, the evil spirits announced themselves to him, fearing his power and authority over them (Mk. 1:23-24, 34; 3:11-12; 5:6-11; Luke 4:33-34; 40-41; 9:41-43). Peter (Acts 5:1-10) and Paul (Acts 10:8-11) could also discern the spirits in individuals or amongst objects or institutions (1 Cor. 10:19; 2 Cor. 11:13-15; Eph. 6:1112; 1 Jn. 3:7-10; 4:1-3).

As for the demoniacs themselves, the Bible indicates a variety that ranges from the lower to the upper class, mostly as antisocial persons, fearing and/or withdrawing from God and community with destructive motives in mind (Mk. 1:23-24; 5:1-7; Lk 4:33-34; 8:27-29; 22:3-4). However, those filled with God's Spirit experience cures (Lk 5:15-16), miracles (Acts $2: 43 ; 5: 12$ ), charismatic raptures (Acts $2: 4 ; 10: 46 ; 19: 6)$, the reading of hearts (Acts 5:3; 8:23), assurance in proclaiming the word (Acts 2:29; 4:13; 
5:20), joy in persecution (Acts 5:41; 21:13), faith (Acts 2:46; 13:52; 16:34), preaching (Acts 8:36) and enlightened human intelligence (Acts 8:26; 16:7; 20:22) (Guillet 1970:40). The character of those filled with God's Spirit can be compared in Acts 8:18 and 16:19 against 20:33 where the magicians' spirit of gain is contrasted with apostolic disinterest in such a motive (Acts 8:20). These examples are evidence of the Spirit's presence among believers. Even so, the ability to identify which spirits are at work does not necessarily resolve whether it is demonic or divine in origin (e.g., 1 Sam. 16:14-16 and compare 2 Sam. 24:1 with 1 Chron. 21:1). For example, in 1 Kg. 22:19-23 and 2 Chron. 18:19-22, the reader can see the Lord dispatch lying spirits to deceive king Ahab's prophets. What one could generally say was that if a spirit was intent on human destruction, it was likely evil; on the other hand, the Holy Spirit would save or empower people to assist others to safety (Wiebe 2004:34). Even then, this observation is not a foolproof criterion.

Discernment of spirits in the early to medieval church period

Beginning with Chrysostom and Tertullian, Christians were expected to be able to discern false prophets and evil spirits. For Chrysostom, it was "knowing who is spiritual and who is not; who is a prophet and who a deceiver" (Thistelton 2000:968). In Tertullian's view, demons and angels could only be known by their effects and their obscure action upon humans (Weibe 2004:38-39). The age before the Nicene period was strongly empirical with phenomena that were supposedly caused by evil spirits. Among the discernment criteria were: intelligible animalistic or inappropriate human speech, raving fits and violence, levitation and extraordinary strength, suffocation, foretelling the future, diseases, mental illness, sacrilegious acts, and dreams of certain kinds (Thistelton 2000:39).

Towards the thirteenth century, debates occurred over the activities of saints, prophets, and mystics to ascertain by what authority such people spoke on behalf of the divine or demonic (Caciola 2003:10,55) If the divine touched ordinary people, then even Popes and princes were subject to their 
utterances. If it were demonic, then yielding to these spirits would produce spiritual and societal anarchy. Also, if the possessed were a mystic saint, they would be venerated; but if it were a demoniac, they would be rejected (ibid., 33). The task of spirit discernment was difficult because no one could observe the inner spiritual disposition of a person but could only scrutinize the outer comportment or behavior (ibid., 2). Especially problematic was that Satan could masquerade as an angel of light (2 Cor. 11:14) and be a liar (Jn. 8:44), thus easily deceiving discerners (ibid., 33).

To better discern the spirits, the church "politics of knowledge production" began to shape the social and religious epistemology of the times; medieval Catholics used 2 Cor. 11:13-15 and 1 Tim. 4:1-2 as starting points. For example, pronouncements of divine oracles made by many ordinary people were tested. At that time large numbers of mystics were women, a matter that threatened the male ecclesiastical order (ibid. 16). Consequently, "disputes over female inspiration tended to juxtapose true inspiration against either diabolic possession or deception [while] debates about controversial males more frequently were couched in terms of doctrinal error or heresy." Women were suspect because by nature they were more "malleable" and "impressionable" than males. Eventually, when the first exorcism manuals were published in medieval times, the "very grammar of the texts assumed that the demoniac would be female" (ibid., 17, 25, 132142). Interestingly, when one compares medieval Catholic discernment typologies, Scriptural mentions of a gender being influenced or possessed by demonic spirits all involve males (see Matt. 9:32-34; 16:23; Mk. 1:23; 5:2; Luke $4: 33 ; 8: 27 ; 9: 41 ; 22: 3) .102$ This view of women later spilled over to early European medical theories that female bodies had greater "physical

102 One exception is Luk. 8:1-4. However, when individuals were accused of being influenced/possessed by demons, males are always mentioned (Matt. 12:24; Jn. 7:19-21; 8:44; 10:20; Acts 10:8-10; 19:16). Thus, if one should establish any gender markers for those who seem more susceptible to demonic possession, it seems more valid to presume males. Interestingly, in American horror films, women are always portrayed as the subject of possessions, not men, whether fictional or based on true events (e.g. "The Exorcist", "Carrie”). The exceptions are zombie movies. However, they do not involve spirit possession but viral infection. 
openness" or "porosity" (i.e., their vagina) which permitted freer entrance to malignant spirits. This logically led to late medieval Christian art depicting fallen angels or demons with physical similarities to women's bodies! Conversely, good angels were all males, and demons were all females (ibid., 161).

Compounding the problem was also a simplistic categorization of the phenomenon that such experiences were either divine or demonic. In this context the connection between demon possession and mental illness was made. Even today, Christian diagnoses of people characterized by mental illness are still easily confused with demonic possession.

The final criterion for discerning the medieval demoniac was that they were antisocial in character; demonization divides the victim from her own senses and community by individual reclusion, frequent fasting, reports of raptures, trances, revelations, penitential remorse as well as demonic torments (ibid., 46-71). The result was that an "identity may be entirely subverted and overwhelmed, as she wholly adopts the new personality and expression of the indwelling spirit that controls her body" (ibid.,130). In spite of these observations, there were reports of demoniacs producing inspired preaching to accept the truths of the Scripture or to castigate others for $\sin$. However, since many experiences could not be truly authenticated, "medieval observers scrutinized what they could: the physical condition of the seer's body and her comportment, especially during the trance state and its immediate aftermath" (ibid., 64). Even Thomas Aquinas encountered difficulty distinguishing between divine and demonic possession.103 If these spirit expressions bordered on the extreme, individuals risked becoming outcasts. However, it was possible that people who were revered (especially females among the lower socio-economic classes) could be tempted to use these manifestations to socially uplift oneself (ibid. 82). Later, Matt. 7:16 would be applied to discern these mostly female mystics to see whether the

103 Aquinas did attempt though to distinguish between ecstasy and rapture: "Rapture adds something to ecstasy. For ecstasy means simply 'to be outside one oneself' [but] rapture adds a certain violence to this" (Caciola 2003:65). 
fruit of their prophecies were either divine or demonic in nature (ibid. 290). However, most medieval Christians were still ultimately unable to truly discern the spirits unless it was believed one was gifted to discern them (ibid., 32-71, 130291).

By the fifteenth century discerners constructed other criteria to mark demoniacs: (1) continual or insistent intimacies with the supernatural only such matters as "obnoxiously insistent supplications for revelations" or "lusts for visions" and (2) extreme penitential practices whose self-judgment was independent from Scripture (ibid., 291-295). Still, no objective tests were presented in which to judge the spiritual content of such expressions. Though it advanced the hermeneutics of spirit discernment, it still assumed external actions accurately confirmed the inner spiritual state.

Throughout the medieval period, church leaders remain convinced that God's Spirit would work only through the church office, not weaker vessels or lay individuals (ibid. 299). The Malleus Maleficarum ("The Witch Hammer") was later produced, becoming the ultimate criteria used to discern witchcraft for over two centuries in Europe (Wiebe 2004: 41). Among the markers were paranormal activities such as speaking in unknown tongues, clairvoyance, and levitation to madness in animals and "normal" activities such as physical deformity, delusions, sudden disease, irrationality, inordinate lusts, paralysis-the latter category of which were all attributed to evil spirits but many which are now judged as natural. Weibe also adds that "[t]he phenomena that provide the strongest intimations that a malevolent form of transcendent reality exists are those that leave traces in the spatiotemporal-causal world or are intersubjectively observable ... such as levitation, unusual strength or the ability to speak unlearned languages ...." (ibid., 58) However, even later male mystics whose spirit expressions were considered suspect were also assigned feminine qualities that made them easy targets of church slander (ibid., 302).

Ignatian Discernment of Spirits 
In the sixteenth century Ignatius developed a distinct form of discernment in his book Spiritual Exercises (Bossche 2004:75-88). He developed "rules ... to feel and discern the different movements produced in the soul ... in order to better discern the spirits ... and recognize the scruples and insinuations of our enemy" (Guillet 1970:81). Ignatius' rules were methods that examined: (1) the conscience to discern three kinds of thoughts, some from the mind and that come completely from one's liberty and will versus those external to the individual, i.e., the good and evil spirit (Ibid., 90) (2) "movements produced in the soul" that are of "consolation," namely experiences that lead one to greater love for God (3) "desolation" or experiences that are contrary to the first two (Bossche 2004:77). On the final criterion, Ignatius remarked that

peace is not just peace and joy is not just joy and desolation is not just desolation ... We have too often seen peace taken to be a movement from and towards God, while in actual fact it was no more than the result of a conflict ended; we have seen joy taken to be the fruit of the Spirit while actually the movement was nothing but Satan moving man into false security, or even the result of a good meal. Desolation was taken to be a movement through which Satan alienates man from God, while in fact the movement was an excess of consolation, of God overwhelming the poor soul with an unmanageable abundance of his peace and love. (Peters 1979:32-33)

Because Ignatian discernment examines the intermingling of these thoughts in the Christian's life (i.e., that of the human spirit, the good and evil spirit), guidance by a spiritual director is key (Bossche 2004:78-79). The director should

offer fitting direction in the way of perfection to beginners, to those making progress and to the perfect ... to examine and recognize the various categories of "spirits", that is to say, "the tendencies and interior movements of souls." Indeed, lacking this discernment and not knowing how to test the 'spirits' come from God, the director risks leading his pupil astray either in the choice of his vocation or on his path to perfection. (Guillet 1970:99) 
When "fitting" discernment occurs, "a kind of supernatural instinct by which those who have it perceive intuitively the origin, either divine or not, of thoughts and inclinations submitted to them" (ibid.,104). To Ignatius the encounter of the human spirit with "two created otherness or spirits stood between the 'border' of the human being's mind" (Bossche 2004:79). This differentiation was not concerned about discriminating between good and evil spirits nor discernment aimed at knowing God but knowing God's will (ibid., 83). Here,

discernment confronts me with the Other who makes me be myself. This confrontation becomes knowledge, in so far as a differentiation occurs. Discernment effects a triple differentiation: between the spirits or the enemy and God on the level of spirits, between the gift and the Giver on the level of the created things, and between the human being and God on the level of the human subject. In this differentiation itself, God is known as the One who makes me live, who gives what is given, and most importantly: who is not me. (ibid.)

Ignatius was also aware that because discernment was a charism or gift, this action must be preceded in prayer, exercising caution in "methods, techniques and so on" (Peters 1979:27-28). The discretio spiritum in the Catholic church is still founded on Ignatius' principles in his Spiritual Exercises. For Roman Catholicism the term means discernment of the "inner movements of our minds and hearts to find and to interpret those that arise under the prompting of the Holy Spirit or the prompting of some spirit in opposition to the Holy Spirit or without the prompting of the either of these" (Toner 1995:11). It is the discernment of the heart and attitudes rather than that of the spirits. This discretio spiritum is about the

preparation for assent to the Holy Spirit, but also as a prevention against connivance with all that is opposed to [God's] designs, with whatever is against true and total love for the Lord and our brothers. Therefore, by the discernment of spirits is meant the process by which we examine, in the light of faith and in the connaturality of love, the 
nature of the spiritual states we experience in ourselves and in others. (Guillet 1970:9)

However, in the twentieth century, spirit possession and discernment took on a different turn as the Catholic church became "reluctant to admit supernatural possession in particular cases ... because naturalistic explanations have become available for many phenomena once deemed demonic" (Weibe 2004:44). Weibe observes that by 1967, the New Catholic Encyclopedia adopted a "cautious stance on the topic of diabolical possession". This newer understanding "exhibits the impact of 60 years of science and biblical criticism on the Catholic church since the older encyclopedia was published". However, Gabriele Amorth, Rome's present chief exorcist disagrees with the new orthodoxy noting that present Catholic leaders prefer to speak about the "spirit of evil" rather than "evil spirits" (ibid., 46). Amorth thus proposed a more lenient criteria than the encyclopedia to discern demonic activity: ordinary temptation, physical pain that does not affect the soul; possession in which full possession of the body occurs, oppression, obsession (which includes sudden attacks of absurd thoughts), infestation (demonic activities upon things other than people) and subjugation (when people consecrate themselves to Satan).

Ignatian discernment is still used today and is concerned with the spiritual progress of the Christian in life. Often, case studies for practical applications of the hermeneutic are needed as no proper discernment of spirits can remain purely theoretical; it must be exercised in real life where people experience the moving of the spirits. Modern Catholic criteria for the

principle of discernment involved in uncovering the [demonic] deception is this: [w] hatever comes from the Holy Spirit is good through and through. Consequently, unless the beginning, middle and the end of the total concrete experience are all good, the whole experience is to be judged as prompted by the evil spirit [thus some] signs to look for are untrue thoughts, unreasonable thoughts, 
thoughts opposed to faith, hope and charity; affections that are sinful or constitute spiritual desolation; thoughts and/or affections that distract from good works; inclinations toward and/or plans for a lesser good than one had previously intended. (Toner 1995: 28-29)

\section{Protestant discernment of spirits}

Early Protestantism identified Satan as key to the Christian's struggle between good and evil (Bossche 2004:79). Today, much of contemporary mainline Protestantism avoids or even denies the presence of the demonic in the Christian life. 104 Its solution to the attacks of historical criticism towards Christianity led to a privatizing of faith and intellectualizing of it as its spirit dimensions, especially demonic ones, were mostly ignored or relegated away. Where spirit discernment occurred, they meant instead attitudes, feelings, and moods under the realm of psychology. These conclusions reduced experiences of the spirit to psychologically induced states that were dreamlike or illusory. All in all, religion was a social construct of humanity in response to societal woes. Any "God-talk" was merely personal.

\section{Evangelical discernment of spirits}

For evangelical Christians, God and demons were real. Their basis rested on their more conservative and literal interpretation of Scripture, its inerrancy and the historical verifiability of Jesus' life and the Spirit's outpouring and presence that came to dwell among Christians who appropriate this abundant life through faith in Christ. For them the objective

104 The exceptions include Paul Tillich, Wolfhart Pannenberg, and Walter Wink. For Tillich see the later section on this. For Pannenberg, though he is relatively sparse concerning direct religious experiences, he validates it (Dumas 2004:187). Concerning Wink, see the later discussion on him with respect to Yong. 
in spirit discernment is "to discover who Jesus is, what he is doing, where his adversary is, and what he is plotting" (Guillet 1970:33).

However, evangelicals also tend to downplay or deny experience, a role in personal guidance or theology (Leibschner 1988:160-161; Parker 1996:10, 173). Even if experience is allowed, they question whose experience and by what criteria should such experience be accorded such a role other than Scripture as the basis for testing the spirits (1 Jn. 4:1-3). Some evangelicals have noted that if charismatic or human/spiritual experiences are starting points for understanding the ontology (or reality of being) and work of the Holy Spirit, it overturns theology on its head by placing experience over theology (Moreau 1997). Yet, their emphasis on reason and the Word alone are insufficient. For example, Augustine, noted that for Scripture, the emphasis is on knowledge, or should we say experiential knowledge, since in order to better understand the Scriptures and tradition, a Christian should existentially 'experience' truth. However, truth must be mediated [as] religious doctrine must not only be understood but it must also be experienced. Reason must penetrate the heart; only then, can the mysteries of faith be experienced as a genuine link to the ultimate reality. (Geybels 2004:57)

There have been attempts however to account for the interaction of Scripture and human condition for discerning spirit experiences. Paul Hiebert (1989:136-138), for example has asked: Does the particular manifestation bring glory to God, honor the Lordship of Christ, and agree with Scriptures? Does the person by whom the manifestation comes exhibit the fruit of the Spirit? Does he or she demonstrate maturity in the faith and a balance in presenting the whole of the gospel? Does the particular manifestation promote unity in the body of Christ or is it divisive?

Others such as the Wesleyans point out in their quadrilateral argument that "Scripture never exists in isolation but only in relation to the tradition of the Church, our exercise of reason and what we experience" (Guillet 1970:46; Yong 2000:217). Thus, any hermeneutic, not just of the 
text, but of also the spirits must account for the experiential and contextual element of the discerner. These dynamics operate when applying an interpretive framework to supply meaning to the situation or entity to be discovered. At the same time, the evangelical commitment to biblical authority and a Christocentric105 approach remain important criteria to judge (1) any form of human or spirit expressions (2) any spirit that does not conform to the biblical tests of 1 Cor. 12:3 and 1 Jn. 4:1-2 and (3) whether any demonic spirit that is at work in the world must be engaged by the Christian, countering error with truth.106

\section{Pentecostal discernment of spirits}

When one surveys Pentecostal or charismatic107 discernment of spirits, the "focus on the demonic is either the exception rather than the rule or it is only briefly mentioned as one of the three sources of motives or impulses to human action (the other two being the human and the divine)"(Yong 2000:244-245). Pentecostals emphasize a different understanding of the Christian life and role of theology. Its hermeneutic affirms that "God acts now in the same ways God did in biblical times [which] provides both an internal as well as an external witness of the Spirit for this age as well as the biblical age (Parker 1996:25 citing McLean).108 For Pentecostals, the point is not to "have an experience or several experiences [but] to experience life as a part of a biblical drama, a

105 This then begs the question whose "Christ" serves as the criterion in which the church and its traditions provide the standard by which such revelations are judged (Parker 1996:164).

106 This may also include exorcism. For evangelical discussions on this, see Anderson (1993), Arnold (1997), Dickason (1987) and Powlison (1995).

107 Although Pentecostals and charismatics are distinct theologically, for the sake of simplicity, I shall refer to both parties as "Pentecostals".

108 On my part, while is it true that God is the same yesterday, today and forever (Heb 13:8), Pentecostals sometimes fail to ask which ways that God moves are the same and which are different. Thus, it is likely an oversimplification to say that God moves in fully the same ways. On this issue, Pentecostals and charismatics need more reflection lest they too fall under the very same theological box that they accuse evangelicals inhabit (i.e., putting "God in a box"). 
participation in God's history" (Land 1993:74-75). In this way, it has been open to many types of spirit expressions. This

conserving of the value of experience does not deny that Pentecostal theology is not a theology of the Word. We do not begin with Schleiermacher's man of religious feelings ... Does this holy experience result in an experience-centered theology? Hardly. The better way to label it is this: Christ-centered, experience-certified theology. (Parker 1996:22 citing MacDonald)

Pentecostal life in the Spirit however cannot be reduced to some part of experience, such as sense perception, conscious experience, cognitive experience, intuition and feeling, religious experience, or any other kind. Rather, there is a thickness and depth to experience, which is more than our attempts to describe and clarify (my emphasis) (Poling and Miller 1985:67).

Tillich (1963:59-66) has remarked that existential concerns are important in any consideration of the spiritual dimension as "questions from human experience should be correlated to answers from revelation". In this light, "disciplines such as psychology and sociology can raise questions about human experiences of brokenness and are also free to provide answers for the transformation of this brokenness alongside answers from the Christian tradition" (Ibid.). As a part of this experience, hermeneutics must be seen as part of a "multi-layered human interpretive activity" (Parker 1996:26). If so, then

'texts' include not only written materials but 'rituals' and the 'communities' that live and practice their interpretations (Ibid.) Pentecostal practice and belief, including the understanding of Scripture, is seen as part of larger questions regarding both the nature of epistemology and hermeneutics. [Consequently] Pentecostal hermeneutics cannot be divorced from the lived Pentecostal tradition, and that what is needed is a methodology that is aware of the various layers of interplay between the knower and the known. (ibid.) 
If common human experience may be a source for theological reflection, then we may include "feelings, moods, commitments, and attitudes as well as information received through the senses, all of which are subject to reflection and interpretation within a community context" (ibid., 45 citing Tracy). This may be modified by "common cultural experience and a more immediate experience (which may have personal or corporate dimensions)" (ibid., 47 citing Tracy). Because each experience is unique and the theological reflections that arise from it bear its influence, every person and culture must be carefully studied without reifying our interpretive categories onto theirs.

Besides the above considerations concerning the role of experience in the theologizing process, Pentecostals also rely on tradition to discern signs of the Spirit. Three markers include (1) appeals to Scripture, especially those dealing with charismatic manifestations (2) the Spirit working in people of good character and (3) the Spirit not physically harming, confusing, nor embarrassing anyone (Parker 1996:105-106). Yong (2000:237) adds that Pentecostal / charismatics also rely on the ability and willingness of the person in question to confess the Lordship of Christ also. All of the above also mean that individual experiences by themselves are of little utility unless they are also understood within the context of tradition or the society of the historical and present believing community (Dumas 2004:191). As the tradition perpetuates these discernment practices of the experience, it also confers aptitude to the discerners through its very repeatability (Hemmings 2004:60.) Lastly, the repeatability of being in continual reflection of Scripture and in the presence of the Spirit in such community hermeneutics also habituates us to sounder methodological processes of discernment.

Between the interplay of the knower, their communities, and of the known text there "also operates in Pentecostal discernment ... certain 'transrational elements' that can be used in drawing a "'practical theology' understood not as the application of theory, but as critical reflection upon the practices of a community of faith" that can be fruitful as a contribution to theological method (ibid.,11-12). According to Yong (2000:224) this 
experience "signifies the conjunction of the divine and human in a manner such that there is a paradoxical tension between the recognition of the Spirit as a divine Thou over and against the I on the one hand, and yet a union between the Spirit and the self that obliterates the subject-object distinction on the other". In addition, the "actual processes of discerning the spirits draws from and integrates perceptual feelings, affective impulses and cognitive judgments into spiritual insights" while at the same time recognizing that no human judgment is infallible (ibid., 254). This process is contrary to the popular stereotype that Pentecostals seem to lack order and instead present an "anything goes" praxis of ministry or worship.

The transrational element derives from 1 Cor. 2:10-15 (Yong 2000:254) and involves human knowing not bounded by reason alone but also the affective dimensions of the self (Parker 1996:11). Such discernment implicates the practices by which "leadings may have their source in the Spirit, in one's own desires, or in diabolical influence" (ibid.,14) 109

It is in these ways that Pentecostal discernment detects the presence of the Holy Spirit, the human spirit, and the evil spirit. A potential danger is that charismatic manifestations can be "one means for validating a leader's authority [as] the ability to regulate [such] manifestations is actually a more powerful leadership role" (Parker 1996:36). Thus, unless a person is willing to allow their interpretation or discernment to be tested by others, there is great temptation to stand as a priest or prophet unto oneself as previously seen in medieval Catholic discernment practices. To check this possibility,

109 For example, there are times when one senses "promptings" of the Spirit that cannot logically be explained. Pentecostals and charismatics likewise argue that similar "sensing" may occur when discerning other spirits as well. Parker (1996:188) citing J.R. Williams comments that in "discussing how the Spirit guides people into truth ... what is imparted by the Spirit is not detailed knowledge of all aspects of Christian truth [but] a deep resonance where the truth exists, whether, for example, it is the truth about God and the world, Christ and salvation or the Holy Spirit and the gifts". See also Tillich (1963:109-112) concerning the "rightness" of experience and Tyra (2011:156) for how these promptings function. However, according Guillet, Pentecostal discernment of spirits can never be considered as a "part of a systematic construction [because] if discernment may lay claim to any conceptual unity, it is that of a habitual self-effacement in order to hear the interior voice of the Spirit [which is] an attitude implying a true experience" (1970:109-110). 
one should minister alongside a discerning community of Christians to develop mature discernment.

\section{Amos Yong's discernment of spirit(s)}

While Parker discusses how Pentecostals discern the Spirit amongst themselves, Yong believes that Pentecostals should also develop a hermeneutic of the discernment of the Spirit among others, i.e., nonChristian religions (2000:10, 200). Because Yong has developed the most sophisticated model to date, I shall discuss him at length here.

From Yong's perspective, the Spirit's presence in understanding others is "the effort to understand both the immensely differentiated experiences of faith and the multifaceted phenomena of religious traditions and systems that is informed by experiences of the Spirit in light of Scripture and vice versa" (ibid., 24). However, since not everything that exists in other traditions is of the Holy Spirit, sure discernment is vital (ibid., 64).

For him, when a person "comes through the experience as a more integrated self bearing the fruits of the Spirit [to this] extent one can say that the Spirit has been present and at work" in their life and ... these expressions edify God's people and transform relationships between Christians and non-Christians (2000:176-177). This agrees with Guillet (1970:44) who comments that "good and evil are recognizable by their fruits [so that] the measure that they are good or evil, their origin is apparent" and that authentic gifts that come from the Spirit are those that "edify the church (1 Cor. 14:4, 12, 26), bring some improvement (1 Cor. 12:7) and contribute to the growth and unity of the body of Christ".

To discern the spirit in other religions, Yong classifies some as "religions of the spirit" that are "frequently dominated by mystical or prophetic types of experiences and expressions, thus capable of being judgmental of both other and of self" (2000:78). For such a venture a robust pneumatology to discern must also include a proper theology and 
hermeneutic of demonology (ibid., 127n). This demonology must account for social structures that operate not just in the heavenly realms but among social or political institutions operated by humans (2003:140).110 Yong notes that they "take on a demonic character when the corporate actions of human beings ensue in destruction and grow beyond human control" (ibid., 131). The demonic can be understood as spiritual "force fields"111 that

neutralize the presence of the Holy Spirit and counter his activity even while they originate and perpetuate destruction and evil in the world. They are legal vectors that which shape the patterns and habits of human activity within cultural institutions, socio-economic networks and political structures ... they can only be discerned from their effects on and instantiations in the concrete actualities of the world. (ibid., 240)

Yong sees demonic force fields as a contrast to that of the Holy Spirit which has a force field of its own. In this light each thing is constituted according to its own norms and is an expression of some ideal or value, by the Spirit's power (ibid., 133).

In order to discern such spirits then Yong believes that spirit discernment is best experienced when the Spirit is seen in a three-fold community hermeneutic (ibid.,112-114). Here, the Spirit is the "supreme relation between us as knowers and the self-revealing God. As a supreme relation, the Spirit is also non-objectifiable and therefore only accessible symbolically" (ibid.,114). In this manner, Yong's conclusion parallels Paul Hiebert's earlier criterion where one

110 Here, Yong relies heavily on Michael Welker's metaphor of force fields and Walter Wink's concept of the powers as a metaphysical aspect for this understanding of the demonic. For details, see Yong (2000:233, 240). 111 Wiebe (2004:55) notes that Tillich has argued likewise, and that its presence can be found at the level of nations when one "nation claims self-elevation over others in the name of its God or system of values and thereby produces a similar reaction from other nations". This implicates discussing territorial spirits which space does not permit. On this, see McConnell (1997) and Wagner (1991). Whether such spirits are territorial or not is not my concern but if they do exist, my concern is how do we discern them. Wink (1986; 1992) also discusses them but see Yong's critique (2003:137) on this. 
looks for concrete signs that follow claims of experiencing the transcendent, [t] he primary norms ... are moral and ethical in nature. For the individual, signs of transformation of soul are especially valuable. Have the religious symbols exhibited the power to affect the transformation of the soul in the devotee? What are the fruits of the individual's change for the better? Is there any evidence of divine activity in the devotee's personal life, ecclesial community or wider networks of relationships? In short, moral-ethical norms gauge the extent of the Spirit's activity in the lives of individuals situated in religious communities and need to be applied to the entire range of human existence. (Yong 2000:251-252)

For Yong, the Holy Spirit assists us to interpret these symbols as pointers to the divine or otherwise. He is the discerner par excellence. At other times there may also be the "absence of divinity" in contrast to degrees of a "fuller" presence of the divine (ibid.,122-125). Discerning the spirits at this level "relates to the functional role of the demonic relative to soteriology" (Ibid.254). When the "fuller" is in view through the presence and work of the Spirit, "the supreme norms, ideals and values instantiated in Jesus are what all things will be judged against" (Ibid.124). When the Spirit moves, it is grounded on Biblical revelation (ibid.,136).112 Part of spirit discernment may also include discerning the types of (demonic) activities that create obstacles to the way of salvation and revelation. Overall, Yong broadens our understanding that spirit discernment should not be confined to spirit entities in individuals but involves spiritual discernment that encompasses all of life (2003:129).

If Yong is correctly understood, how this works might be seen in Jesus' discernment of the spirits in Matt. 16:15-23. Peter, by the revelation of God's Spirit realizes the truth of Christ which Jesus discerns and affirms. However,

112 One may wonder why Yong does not come to the point and insist that all that the Spirit does eventually points to a Christological foundation in his hermeneutics of discernment. However, Yong's interest lies in pursuing a more pneumatological angle than Christological one. While the Christological dimension is always present as discernment criterion (i.e., 1 Jn. 4:1-3), Yong considers the pneumatological aspects as less developed and thus the focus of his inquiry (ibid: 58 ). 
following this, influenced by another spirit, Peter denies Christ's work to accomplish God's will. Because Jesus discerned and revealed Satan's role and effect on Peter, the latter was rebuked even though he was earlier influenced by God's Spirit. In Peter's case, the human spirit lost its selfcontrol. One of the fruits of the Spirit is self-control (Gal 5:22) and when this is absent it may result in human behavior that is not only extremely aberrant but leads to a destruction in the self, relationship with others, and disharmony with biblical truth-all possible signs of demonic influences on the human spirit. However, when the human spirit heeds the Holy Spirit, the human conscience's role in allowing God to be heard is amplified as the human spirit flows in symbiosis with the Holy Spirit (1 Cor 14:32).

If Yong's hermeneutic ideally works in the above example, the criterion of the divine absence/presence to discern the Spirit can be critiqued. For example, it is unclear how his hermeneutic functions when both good and evil spirits may originate from God and when they lead people to destruction or deceptive confusion (e.g., Judg 9:23; 1 Sam 16:14-23; 18:10; 19:9; 2 Kings 19:7; 2 Chron. 18:18-22; Is. 19:14; 29:10)!

Another weakness is that Yong's discussions of the Spirit loses "an immediate personal context [and] lacks an emphasis on the people of other faiths-these seem secondary, rather than primary" (Lord 2005:100). The Holy Spirit also seems abstract if not more of a force in Yong's conception.113 In examining Yong, one can conclude that the

experience of the Holy Spirit need not be christologically perceived [as] the Spirit of God is at work in ways of which we are not aware. But for the Christian, the criteria for discernment of the Spirit cannot be other than Christological. What defines Christians as Christians is that they understand the Spirit of God to be the Spirit of Jesus Christ who is revealed in the Bible. This is the only criterion for discernment on which Christians can agree (Kim 2007:167).

113 For example, Yong hardly mentions the Holy Spirit by the personal pronoun "his". In Beyond the Impasse, only one use is found on p.135. For other critiques of Yong, see Ott, Strauss, and Tennent (2010:308-309). 
The gift of discernment of spirit

Now there are varieties of gifts, but the same Spirit; and there are varieties of services, but the same Lord; and there are varieties of activities, but it is the same God who activates all of them in everyone. To each is given the manifestation of the Spirit for the common good ... to another the working of miracles, to another prophecy, to another the discernment of spirits ...." (1 Cor. 12:4-10)

At this point, one final aspect remains unexamined: what does the "gift" of "discernment of spirits" mean in 1 Cor 12:10? Current scholarship generally holds two positions. The first is that it involves judging or evaluating spirit-inspired speech that is prophetic (Collins 1999:455; Garland 2002:583; Fee 1994; McNamara 1970:6). This would allow one to know whether some are preaching "another Gospel" (Gal 1:6) or "another Jesus" (2 Cor. 11:4) (Garland 2002:583). Aquinas held to a variation of this view, remarking that discretio spiritum is a gift that

permits the man who teaches the things of God to "confirm" what he says. This "confirmation" may be effected by various gifts, by showing that it is proper to God alone to have knowledge of future contingencies (my emphasis); it is in view of this that reference is made to the gift of prophecy and then the gift of knowing the secrets of hearts". (cited by Guillet 1970:68)

The second position is that it concerns distinguishing between evil versus the Holy Spirit (Grudem 2000:55). Anthony Thiselton believes that it includes "a critical capacity to discern the genuine transcendent activity of the Spirit from merely human attempts to replicate it and a pastoral discernment of the varied ways in which the spirit of God is working in such a way as to distinguish various consequences and patterns" (2000:967). 
For both views, we must not risk "individualizing and even trivializing Paul's more corporate and strategic concerns about discerning the ways of the spirit" (ibid., 969). This is because discernment is both the individual and community's responsibility as the Spirit has poured out gifts to both. Thus, the use of this gift involves more than arbitrating "small-scale controversies between individuals in local communities or minor variants between traditions of interpretation" (ibid.). If a wider view is taken, then the gift of discernment of spirits can also include Christians serving in any sense of the Spirit's work with respect to other spirits in the larger context of the church's mission in the world (Yong 2003:102). Whether individually or corporately, Scripture does indicate that people who do possess this gift can discern demonic spirits in religious others (Matt. 16:16-23; Acts 5:1-4). If Christians may accept the existence of such a gift, to whom this may be given we do not know, but when such individuals are present and discovered, the church should not neglect its use in any engagement of religions. However it is exercised, they should be led by the Spirit to guide others into all truth (Jn. 16:13).

\section{Constructing a hermeneutical matrix for the discernment of spirits}

At this point an assessment of the various models can be summarized and reconstituted under a proposed hermeneutic matrix for the discernment of spirits that harvests the strengths and insights of each approach:

1. Context: spirit discernment involves distinguishing between three or more spirits in each situation or context. The spirits that exist in this world that require discernment of their presence are the human spirit, evil spirit, Holy Spirit, angelic spirits, and possibly the zeitgeist of society (Guillet 1970:77). 114

114 I have modified Guillet's criteria to include zeitgeist, which means the "spirit of the age". It may involve real spirit entities or merely the socio-cultural and religious milieu in which we live and breathe. 
2. Character-consistency: it involves discerning a spirit's work in a person's psychological profile to assess the soundness of their character and personality (i.e., the human spirit). For instance, do such spirits or experiences

a. leave them with a sound mind? While the Holy Spirit does not physically harm nor embarrass anyone, we should be cautious lest we misread what certain bodily manifestations of spiritual experiences may mean. They must be ascertained within the context of the community, history of the individual, and the society and biblical data, as to whether such behavior is demonic or truly Holy Spirit inspired.

b. lead them to greater maturity in their personal emotions? The Holy Spirit will work to increase psychological and emotional maturity as part of God's work. It should also produce the fruit of the Spirit (Gal 5:22-23) and transform their mind (Rom 12:1-2). God's Spirit never destroys the imago Dei within but seeks to bring people to fullness in their soul, mind and being. 115 Among them, people should think the thoughts of God (Phil 4:8): "Finally, brothers, whatever is true, whatever is worthy of respect, whatever is just, whatever is pure, whatever is lovely, whatever is commendable, if something is excellent or praiseworthy, think about these things."

c. reflect a historical consistency of growth in their character and personality that leads to increased personal holiness (i.e., are they becoming better persons over time)?

d. occur among the social middle or marginal individuals? Typically people from the social margins may exhibit behavior that seeks to draw attention to themselves. Careful examination should be made to ascertain whether they are merely psychological insecurities expressed that we misinterpret as led by the Spirit or by manifestations of the demonic. 
3. Community: it involves communal discernment and engages God's people, the general society and its institutional systems that work for the common good. This is the external-communal component of discernment. It asks whether such spirits or experiences

a. invite and provide for individuals or structures to self-examine community ills. This presumes community involvement that considers all aspects of its life and includes the resources of that community's wisdom. If Christians are present, those with spiritual discernment can be essential in bringing biblical wisdom to the culture.

b. impact and/or transform the community for the good or worse. This assumes that the community as a whole is not at odds against the biblical worldview and by itself also exhibits many traits of a socially healthy and caring community. This should also be contrasted against biblical communities of church history and its historical, orthodox teachings as well.

c. lead people to greater community involvement (see first point). In this way, "action, not theory, is the arena for testing truth claims [as] truth is discovered through involvement" (Parker 1996:43).

4. Content: it relies on an objective discerning standard (i.e., Scripture) to achieve evidential consensus amongst all Christians. This is the transcendental-objective component of discernment. It asks whether such spirits or experiences resonate with biblical truths and square with the revelation of Christ as revealed by the triune God's witness through the Holy Spirit (Jn. 16:13-15).

\section{E. Theological, pastoral, and missiological implications}

To better understand the nature of spirit influences among nonChristians and avoid simplistic categorizations of good versus evil spirits, one should ask how do religious communities understand experiences of the transcendent (Caciola 2003:22)? A comparative theology that involves the "hermeneutical process of identifying, classifying and interpreting the 
similarities and differences between religious symbols" is needed so that we understand a "thing's authentic representation of its being and accomplishment of its purpose relative to others" and how its insiders see it as well (Yong 2000:142-143).

However, engaging other religions empirically means that Christians need a dialectic between our constants and their reality. This dialectic must occur not just at the phenomenological but also at the ontological and theological levels. Who are they? What do they say? What is manifested?

Discernment however cannot remain purely at the ontological realm. It is also sociological and situated within a tradition and society that provides coherent plausibility structures as to what is divine, demonic, or otherwise. For followers of Christ the biblical worldview is understood and experienced within the historical, interdenominational, and global church, which must lay down the plausibility structure and vision par excellence of a Christian community. This guides and becomes the community by which all other worldviews and hermeneutics are judged and transformed towards truth (Jn. 14:6), good works (Mic. 5:2), and also emotional and mental wholeness into Christlikeness by God's Spirit. Missiologically, the discernment of spirits implicates evangelism (e.g., knowing how God's Spirit is working among others), discipleship (e.g., understanding the heart or "spirit" of the convert) and societal transformation (e.g., examining the zeitgeist in social, institutional structures). The church identifies not only the presence of opposing spirits but also the historical tides as well as social and community traditions of others on a larger level.

Finally, spirit discernment is a mystery we will never fully grasp. Any experience of fully knowing or discerning transcendent entities comes only when God allows humans to better see what he sees (Hemming 2004:72-73). For this reason, prayer and humility is the proper Christian posture as divine wisdom is always necessary. Because discernment is God's gift to Christians, we must be good stewards of this gift and its purpose so that we nurture it among those of us who may possess it. 
We must also avoid polarizing views of "us" versus "others" in seeing demonic influences among non-Christians. In addition, we need to develop a critical psychological, anthropological, and sociological analysis of people, lest we rush towards simplistic answers for what may be complex psychosocial (Moore 1977) or large scale societal phenomena (Ong 1987). When training pastors or missionaries for this task we should encourage the collection of case studies from the field. This multi-perspective approach can only occur in real-life ministry settings in touch with a wise and discerning community of believers who are working in cooperation with one another. Such a community should be sufficiently diverse in its theological orientation and practice so that no one tradition can claim interpretive ultimacy, with a temptation to claim power over others, as to what is demonic or divine among people who are unlike them. Finally, because the Spirit

"blows where it will" (John 3:8) ... one cannot simply generate a list of guidelines that chart the ways the Spirit can and will move. [Spirit expressions] should not be used to avoid the hard questions of life. Discerning the divine will always involve risk; there is no way to know for certain whether one's choices or allegiances are ultimately the right ones [as] human fallibility suggests that all decisions, even those made under the leading of the Holy Spirit, need periodic review"(Parker 1996:202).

\section{REFERENCES}

Anderson, Neil. 1993. The Bondage Breaker. Eugene, OR: Harvest House.

Arnold, Clinton. 1997. Three Questions About Spiritual Warfare. Grand Rapids, MI: Baker.

Bossche, Stijn Van Den. 2004. Experience and Knowledge of God through Ignatian 'Discernment of Spirits'. In Divinising Experience: Essays in the History of Religious Experience from Origen to Ricoeur. Lieven Boeve and Laurence P. Hemming, eds. Dudley, MA: Peeters. Pp.75-88.

Caciola, Nancy. 2003. Discerning Spirits: Divine and Demonic Possession in the Middle Ages. Ithaca, New York: Cornell University Press. 
Collins, Raymond F. 1999. First Corinthians (Sacra Pagina Series 7). Collegeville, MN: Liturgical Press.

Department of Statistics Malaysia. 2010. Census 2010.

www.statistics.gov.my/portal/_download_Population/files/census2010/Taburan_Penduduk_dan_Ciriciri_Asas_Demografi.pdf (accessed May 28, 2012).

Dickason, C. Fred. 1987. Demon Possession and the Christian. Wheaton, IL: Crossway.

Dumas, March. 2004. Theological Methodology, Religious Experience, and Christian Faith in the Writings of Wolfhart Pannenberg. In Divinising Experience: Essays in the History of Religious Experience from Origen to Ricoeur. Lieven Boeve and Laurence P. Hemming, eds. Dudley, MA: Peeters. Pp.179-225.

Eadie, Betty J. 1992. Embraced by the Light. Placerville, CA: Gold Leaf.

Fee, Gordon. 1985. 1 Corinthians. (New International Commentary on the New Testament). Grand Rapids, MI: Eerdsman.

1994. God's Empowering Presence: The Holy Spirit in the Letters of Paul. Peabody, MA: Hendrickson.

Foster, Richard, 1988. Celebration of Discipline: The Path to Spiritual Growth. San Francisco, CA: HarperSanFrancisco.

Garland, David. 2000. 1 Corinthians. (Baker Exegetical Commentary on the New Testament). Grand Rapids, MI: Baker.

Geybels, Hans. 2004. Experience Searching for Theology and Theology Interpreting Experience: Augustine's Hermeneutics of Religious Experience. In Divinising Experience: Essays in the History of Religious Experience from Origen to Ricoeur. Lieven Boeve and Laurence P. Hemming, eds. Dudley, MA: Peeters. pp.33-57.

Grudem, Wayne. 1982. The Gift of Prophecy in 1 Corinthians. Lanham, MD: University of America Press. 2000. The Gift of Prophecy in the New Testament and Today. Wheaton, IL: Crossway. 
Guillet, Jacques, et al. 1970. Discernment of Spirits. Collegeville, MN: Liturgical Press.

Hanegraaff, Hank. 1993. Christianity in Crisis. Eugene, OR: Harvest House.

Hemming, Laurence. 2004. The Experience of God: Aquinas and the Identity and Difference of Divine and Human Knowledge. In Divinising Experience: Essays in the History of Religious Experience from Origen to Ricoeur. Lieven Boeve and Laurence P. Hemming, eds. Dudley, MA: Peeters. pp.58-74.

Hiebert, Paul G. 1989. Healing and the Kingdom. In Wonders and the Word: An examination of issues raised by John Wimber and the Vineyard Movement. Ed., James R. Coggins and Paul G. Hiebert, 109-152. Winnipeg: Kindred Press.

1994. Anthropological Reflections on Missiological Issues. Grand Rapids, MI: Baker.

Hillstrom, Elizabeth. 1995. Testing the Spirits. Downers Grove, IL:IVP.

Kim, Kirsteen. 2007. The Holy Spirit in the World: A Global Conversation. Maryknoll, NY: Orbis.

Kostenberger, Andreas. 2008. Father, Son and Spirit: The Trinity and John's Gospel. Downers Grove, IL: IVP Academic.

Land, S. 1993. Pentecostal Spirituality (Journal of Pentecostal Theology Supplement Series 1). Sheffield, UK: Sheffield Academic Press.

Lehmann, Arthur C. and James E. Myers. 1997. Magic, Witchcraft and Religion: An Anthropological Study of the Supernatural. Mountain View, CA: Mayfield.

Liebschner, Sigfried. 1988. The Experience of Guidance by the Holy Spirit. In Christian Experience in Theology and Life (Papers read at the 1984 Conference of the Fellowship of European Evangelical Theologians). I. Howard Marshall, ed. Edinburgh: Rutherford House. pp. 159-174.

Lord, Andrew. 2005. Spirit-Shaped Mission: A Holistic Charismatic Missiology. Waynesboro, GA: Paternoster. 
McBain, Douglas. 1992. Discerning the Spirits: Checking for Truth in Signs and Wonders. London, U.K: Marshall Pickering.

McConnell. C. Douglas., ed. 1997. The Holy Spirit and Mission Dynamics (Evangelical Missiological Society Series No.5). Pasadena, CA: William Carey Library.

McNamara, Martin. 1979. Discernment Criteria in Israel: True and False Prophets. In Discernment of the Spirit and of Spirits. Christian Duquoc and Casiano Floristán Samanes, eds. New York, NY: Seabury Press.

Moore, E. Garth. 1977. Try the Spirits: Christianity and Psychical Research. New York, NY: Oxford University Press.

Moreau, A. Scott. 1997. Broadening the issues: Histeriographic, advocacy, and hermeneutics. In The Holy Spirit and Mission Dynamics. (Evangelical Missiological Society Series No.5) McConnell. C. Douglas., ed., 121-135. Pasadena, CA: William Carey Library.

Musk, Bill. 1988. Dreams and the Ordinary Muslim. Missiology 16 (2):163-172.

Ong, Aihwa. 1987. Spirits of Resistance and Capitalist Discipline: Factory Women in Malaysia. Albany, NY: State University of New York Press.

Ott, Craig L., Steve J. Strauss and Timothy C. Tennent. 2010. Encountering Theology of Mission. Grand Rapids, MI: Baker Academic.

Parker, Stephen E. 1996. Led by the Spirit: Toward a Practical Theology of Pentecostal Discernment and Decision Making. (Journal of Pentecostal Theology Supplement Series 7). Sheffield, UK: Sheffield Academic Press.

Peters, William. 1979. Ignatius of Loyola and 'Discernment of Spirits'. In Discernment of the Spirit and of Spirits. Christian Duquoc and Casiano Floristán Samanes, eds. New York, NY: Seabury Press. Pp.1734.

Poling, J. and Donald Miller. 1985. Foundations for a Practical Theology of Ministry. Nashville, TN: Abingdon.

Powlison, David. 1995. Power Encounters: Reclaiming Spiritual Warfare. Grand Rapids, MI: Baker. 
Rago, D. Scott. 1983. Leaving the Body. New York: Prentice Hall.

Samanes, Casiano Floristán and Christian Duquoc, eds. 1979. Discernment of the Spirit and of Spirits. New York, NY: Seabury Press.

Thistelton, Anthony. 2000. The First Epistle to the Corinthians. Grand Rapids, MI: Eerdsman.

Tillich, Paul. 1963. Systematic Theology, Volume I-III. Chicago, IL: University of Chicago Press.

Toner, Jules. 1995. Spirit of Light or Darkness? A Casebook for Studying Discernment of Spirits. St. Louis, MO: Institute of Jesuit Sources.

Tyra, Gary. 2011. The Holy Spirit in Mission: Prophetic Speech and Action in Christian Witness. Downers Grove: IL: IVP Academic.

Wagner, C. Peter. 1988. The Third Wave of the Holy Spirit: Encountering the Power of Signs and Wonders. Ann Arbor, MI: Vine Books.

1991. Territorial Spirits. Ventura, CA: Regal.

Wiebe, Phillip H. 2004. God and Other Spirits: Intimations of Transcendence in Christian Experience. New York: Oxford University Press.

Wilson. Stephen. 2000. The Magical Universe: Everyday Ritual and Magic in Pre-modern Europe. New York, NY: Hambleden and London.

Wink, Walter. 1986. Unmasking the Powers: The Invisible Forces that Determine Human Existence. Minneapolis, MN: Fortress Press.

1992. Engaging the Powers: Discernment and Resistance in a World of Domination. Minneapolis, MN: Fortress Press. 
Yong, Amos. 2000. Discerning the Spirit(s): A Pentecostal-Charismatic Contribution to Christian Theology of Religions. Sheffield, UK: Sheffield Academic Press.

2003. Beyond the Impasse: Beyond a Pneumatological Theology of Religions. Grand Rapids, MI: Baker Academic.

Short biography of author:

Dr Cheong Weng Kit serves at Sabah Theological Seminary in Malaysia as a fulltime lecturer in missiology and intercultural studies. He has a ThM and a $\mathrm{PhD}$ in Intercultural Studies. He researches and writes on Asian Pentecostalism, work, money and mission, globalisation and world religions. He has edited three books and published over 30 articles on the Trinity, Pentecostalism, mission and world religions, contextual theology, globalisation and urban missiology.

\section{Contact information:}

Dr Cheong Weng Kit

c/o Sabah Theological Seminary

26 Jalan Pinggir, off Jalan Istana

88400 Kota Kinabalu

Sabah

MALAYSIA.

Email: wkcheong@stssabah.org 